\title{
Scientific Research, Firm Heterogeneity and Foreign R\&D Locations of Multinational Firms
}

Citation for published version (APA):

Belderbos, R., Leten, B., \& Suzuki, S. (2017). Scientific Research, Firm Heterogeneity and Foreign R\&D Locations of Multinational Firms. Journal of Economics \& Management Strategy, 26(3), 691-711. https://doi.org/10.1111/jems.12205

Document status and date:

Published: 01/01/2017

DOI:

10.1111/jems.12205

Document Version:

Publisher's PDF, also known as Version of record

Document license:

Taverne

Please check the document version of this publication:

- A submitted manuscript is the version of the article upon submission and before peer-review. There can be important differences between the submitted version and the official published version of record.

People interested in the research are advised to contact the author for the final version of the publication, or visit the DOI to the publisher's website.

- The final author version and the galley proof are versions of the publication after peer review.

- The final published version features the final layout of the paper including the volume, issue and page numbers.

Link to publication

\footnotetext{
General rights rights.

- You may freely distribute the URL identifying the publication in the public portal. please follow below link for the End User Agreement:

www.umlib.nl/taverne-license

Take down policy

If you believe that this document breaches copyright please contact us at:

repository@maastrichtuniversity.nl

providing details and we will investigate your claim.
}

Copyright and moral rights for the publications made accessible in the public portal are retained by the authors and/or other copyright owners and it is a condition of accessing publications that users recognise and abide by the legal requirements associated with these

- Users may download and print one copy of any publication from the public portal for the purpose of private study or research.

- You may not further distribute the material or use it for any profit-making activity or commercial gain

If the publication is distributed under the terms of Article $25 \mathrm{fa}$ of the Dutch Copyright Act, indicated by the "Taverne" license above, 


\title{
Scientific research, firm heterogeneity, and foreign R\&D locations of multinational firms
}

\author{
René Belderbos $^{1,2}$ ～Bart Leten ${ }^{3,4}$ ～Shinya Suzuki ${ }^{5}$
}

\author{
${ }^{1}$ Faculty of Economics and Busi- \\ ness, KU Leuven, Leuven, Belgium \\ (Email: Rene.Belderbos@econ.kuleuven.be) \\ ${ }^{2}$ University of Maastricht and UNU-MERIT, \\ Maastricht, The Netherlands \\ ${ }^{3}$ Faculty of Economics and Busi- \\ ness, KU Leuven, Leuven, Belgium \\ (Email: Bart.Leten@econ.kuleuven.be) \\ ${ }^{4}$ Faculty of Economics, University of Hasselt, \\ Hasselt, Belgium \\ ${ }^{5}$ Musashi University, Tokyo, Japan \\ (Email: s.suzuki1@cc.musashi.ac.jp)
}

\begin{abstract}
We examine the influence of host countries' scientific research strengths on global R\&D location choices by multinational firms. In an analysis of 277 new R\&D activities identified for 175 firms in 40 host countries and 30 technology fields, we find that the strength of relevant university research positively affects the likelihood that host countries attract foreign R\&D. When allowing for firm heterogeneity, university scientific research appears only a significant factor for firms with a strong science orientation in their R\&D activities. Host countries' corporate scientific research has no systematic influence on R\&D location choices. Empirical results are replicated in an analysis at the regional level covering regions in Europe, the United States, and Japan.
\end{abstract}

\section{1 | INTRODUCTION}

An expanding literature on the importance of science for industrial research has suggested that proximity to, and involvement in, academic research, as well as formal collaborative research with academia increases the innovative performance of firms (e.g., Cassiman, Veugelers, \& Zuniga, 2008; Cockburn \& Henderson, 1998; Cohen, Nelson, \& Walsh, 2002; Fleming \& Sorenson, 2004; Furman Kyle, Cockburn, \& Henderson, 2010; Gambardella, 1992; Jaffe, 1989; Jaffe et al., 1993; Mansfield, 1995; Zucker, Darby, \& Armstrong, 2002). Empirical studies have, furthermore, shown that academic research stimulates the growth of local industrial R\&D and the setup of new research intensive ventures in the region (e.g., Abramovsky, Harrison, \& Simpson, 2007; Anselin, Varga, \& Acs, 1997; Bania, Calkins, \& Dalenberg, 1992; Bonaccorsi, Colombo, Guerini, \& Rossi-Lamastra, 2013; Furman \& MacGarvie, 2007; Jaffe, 1989; Zucker, Darby, \& Brewer, 1998). However, surprisingly little attention has been given in the literature to the role of academic research in the global $R \& D$ location choices by multinational firms. ${ }^{1}$ It is important to examine this role, as foreign $R \& D$ represents an increasing share of the R\&D activities of multinational firms and of total business R\&D expenditures in many countries (e.g., OECD, 2007; UNCTAD, 2005).

In this paper, we seek to understand to what extent scientific research strengths of (potential) host countries affect the probability that multinational firms locate $R \& D$ activities in these host countries. We argue that firms are heterogeneous with respect to their responsiveness to host country scientific research. Firms possess different capacities to recognize, absorb, and utilize scientific knowledge (Cohen \& Levinthal, 1990; Fabrizio, 2009; Gambardella, 1992; Rosenberg, 1990), which is likely to be reflected in the science orientation of their R\&D and technology development activities (Furman, 2003; Liebeskind, Oliver, Zucker, \&

\footnotetext{
We thank Bart Thijs and Wolfgang Glanzel for assistance in the analysis of ISI publication data at the Centre for R\&D Monitoring (ECOOM) of the KU Leuven, and Shanqing Du for research assistance. We acknowledge financial support from EU FP7 grant number SSH7-CT-2008-217436. We are grateful to Daniel Spulber; two anonymous reviewers; Lee Fleming; Jan van Hove; Reinhilde Veugelers; Bart Van Looy; Leo Sleuwaegen; and participants at the EU Conference on Corporate R\&D (Seville, October 2007), the ESF/COST workshop in Leuven (October 2007), the Global Innovation Management workshop (Duisburg, February 2008), the 2008 AIB Conference (Milan, June 2008), the 2008 SMS Conference (Köln, October 2008), the INIR Workshop on the Global Laboratory (Leuven, November 2008), the CEPR SCIFI-GLOW Workshop (Madrid, July 2009), and workshops at Hitotsubashi University (July 2009), RIETI (August 2009), and Copenhagen Business School (2011) for comments on earlier drafts.
} 
Brewer, 1996). Firms with a more outspoken science orientation in R\&D activities will attach greater value to the presence of local academic research and may weigh this factor stronger in foreign R\&D location choices. We examine the science orientation of firms' R\&D activities as a key moderator variable by looking at the intensity with which scientific publications are cited in firms' prior patent applications. By examining firm-level heterogeneity in the valuation of location-specific characteristics, we extend earlier work on firm heterogeneity in location choices emphasizing other firm traits, with technology leadership the main focus of attention (Alcacer \& Chung, 2007; Nachum, Zaheer, \& Gross, 2008; Shaver \& Flyer, 2000). We contrast science orientation with technology leadership as alternative dimensions of firm heterogeneity to examine their relative explanatory power as a moderator of firms' responsiveness to academic research in R\&D location choices. In addition to investor heterogeneity, we examine heterogeneity in the actors behind the generation of host countries' scientific research, distinguishing academic research by university authors and research conducted by firm scientists (corporate scientific research).

We examine foreign R\&D location choices at the microlevel, using patent-derived information on new or expanded R\&D activities at the technology field level (30 fields) for 175 R\&D intensive European, U.S., and Japanese firms in the chemicals, pharmaceuticals, engineering, IT hardware, and electronics industries in 40 host countries for the periods 1995-1998 and 1999 2002. Inferring R\&D locations from inventor information on (European Patent Office [EPO]) patent documents, we identified 277 cases in which firms recorded substantive R\&D activities in particular technology fields in one of the host countries for the first time. We construct indicators of the scientific output of universities and firms using annual ISI publication data. We count publications at the level of countries, publishing organizations, and science fields, and take into account the relevant publications for each technology field using a concordance matrix linking technologies to the set of science fields on which they draw most. We estimate conditional logit models with country fixed effects and exploit variation in host countries' relevant scientific research strength across countries, technologies, and time to identify the impact of scientific research on R\&D location choices of firms. The analysis controls for the main alternative key driver of R\&D location decisions: the attraction of clusters of industrial R\&D activities in the host country. We measure industrial R\&D at the country and technology level as the number of patents applied for in the field by host country inventors. We control for prior operations of the firms in the host countries and a broad set of other host country characteristics that in prior research have been found to attract or discourage foreign R\&D activities. This setup allows us to determine the significance and magnitude of the impact of scientific research on multinational firms' R\&D location choices with greater precision.

We find that university research strength in a host country positively affects the probability that the country is chosen as the location for new R\&D activities, while corporate scientific research does not affect multinational firms' R\&D location choices. Allowing for firm heterogeneity reveals that university research strength is a significant factor for firms with a strong science orientation in their prior R\&D activities, while university research plays no significant role for firms with a more limited science orientation. Firms' technology leadership, in contrast, is not an independent differentiator for the responsiveness to university research strength. Rather, among firms with a strong science orientation, technology laggards are most attracted to university research strengths. The core results are robust to changing the level of analysis from the country level to the regional level.

\section{2 | DRIVERS OF FOREIGN R\&D}

Two streams of literature inform about the role of academic research in firms' foreign R\&D location choices: the R\&D internationalization literature and the literature on university-industry linkages.

\section{1 | International R\&D}

Studies on international R\&D by multinational enterprises (MNEs) have identified two major motivations to set up foreign R\&D activities (e.g., Criscuolo, Narula, \& Verspagen, 2005; Driffield, Love, \& Menghinello, 2010; Florida, 1997; Hakanson \& Nobel, 1993; Kuemmerle, 1997; Phene \& Almeida, 2008; Song, Asakawa, \& Chu, 2011). Traditionally, MNEs have conducted $\mathrm{R} \& \mathrm{D}$ activities outside their home countries to support manufacturing activities of local subsidiaries or to adapt products and technologies developed in their home countries to local market conditions ("home base exploiting" or "adaptive" R\&D). A second major motivation for international R\&D is to develop new technologies overseas by accessing foreign R\&D resources and local technological and scientific strengths ("home base augmenting" or "innovative" R\&D). Empirical studies have suggested that home base augmenting R\&D is gaining importance (e.g., Ambos, 2005; Ambos \& Ambos, 2011; Florida, 1997; Kuemmerle, 1997; OECD, 2007; Todo \& Shimizutani, 2008; Von Zedtwitz \& Gassmann, 2002). The rise in home base augmenting R\&D has drawn renewed attention to the question to what extent home country operations can benefit from overseas R\&D through "reverse" technology transfer and the development and sharing of complementary technologies. Although some studies have 
indicated that knowledge flows from foreign affiliates back to headquarters have remained limited (Fors, 1997; Frost, 2001; Gupta \& Govindarajan, 2000), recent evidence suggests that there are knowledge flows from host country organizations to foreign affiliates of MNEs (Singh, 2007) and that foreign R\&D can have a positive impact on MNE productivity (e.g., Griffith, Harrison, \& Van Reenen, 2008; Harhoff, Mueller, \& van Reenen, 2014; Iwasa \& Odagiri, 2004; Lahiri, 2010; Nieto \& Rodriguez, 2011; Penner-Hahn \& Shaver, 2005; Todo \& Shimizutani, 2008).

A large number of studies have examined the factors that contribute to the explanation of the location and intensity of foreign R\&D conducted by multinational firms (e.g., Belderbos, 2003; Kuemmerle, 1999; Kumar, 2001; Shimizutani \& Todo, 2007). These studies have shown that the presence of foreign R\&D is closely related to the extent of local manufacturing activities of the firm and often follows Foreign Direct Investment (FDI) in manufacturing with some time lag. Proximity to manufacturing is often required for applied engineering and product development in order to appropriately adapt products to local markets (e.g., Kenney \& Florida, 1994). Foreign R\&D is also attracted to large and sophisticated local markets with high per capita income levels. R\&D in proximity to lead users helps companies to stay at the forefront of market and technological developments and to recognize and respond to changing customers' demands (Cantwell \& Mudambi, 2005; Von Zedtwitz \& Gassmann, 2002).

Prior studies suggest that the technological strength of host countries in fields in which the multinational firm is active is a factor that influences location decisions. Patel and Vega (1999) and Le Bas and Sierra (2002) examined patent portfolios of a large sample of firms and showed that in a majority of technological fields, firms tend to locate foreign R\&D in host countries that are specialized in those fields. Related evidence by Chung and Alcacer (2002) suggested that technical capabilities of U.S. states attract foreign manufacturing activities if these firms are active in R\&D intensive industries. Other factors that have been found to attract foreign $R \& D$ are large pools of engineers and scientists at relatively low cost (e.g., Booz Allen Hamilton and INSEAD, 2006; Frost \& Sullivan, 2004; Lewin, Massini, \& Peeters, 2009; Thursby \& Thursby, 2006) and strong intellectual property right regimes (Allred \& Park, 2007; Branstetter, Fisman, \& Foley, 2006).

\section{2 | Academic research and industrial (foreign) R\&D}

Universities may influence firms' innovation activities in several ways. They educate and supply firms with a skilled labor force of scientists and engineers, supply consultants on expert issues, serve as collaboration partners in applied or basic research, and transfer new prototypes and embryonic technologies to firms (Cassiman et al., 2008; Hall, Link, \& Scott, 2003). Last but not least, they perform academic research. Academic research generates (basic) scientific knowledge on which firms can draw in their applied R\&D activities (Klevorick et al., 1995; Mansfield, 1995, 1998). Firms that are aware of, and can assimilate, developments in relevant scientific fields may be able to develop a deeper understanding of the technological landscape in which they search for new inventions (Fleming \& Sorenson, 2004; Rosenberg, 1990). This can provide several benefits. Firms may better anticipate the outcomes of research experiments, helping them to prioritize research avenues, and to avoid costly and time-consuming research trials that lead to low-value outcomes (Fabrizio, 2009; Fleming \& Sorenson, 2004). In addition, scientific knowledge may help firms to evaluate the outcomes of their applied research activities and to better assess the (economic) implications (Rosenberg, 1990). Finally, revolutionary scientific discoveries can open up completely new areas of applied research and development, and firms that are closely following scientific research may be among the first to translate basic research results in applied technology development (Fabrizio, 2009). Although these are different mechanisms through which multinational firms could benefit from scientific research in host countries, we note that our analysis is not able to distinguish the individual mechanisms, but relates $R \& D$ location decisions to the strength or relevant scientific research in host countries.

In order to capture the multiple benefits of academic research, firms often need a local R\&D presence. This allows the firms' researchers to participate in local science networks and acquire tacit knowledge through frequent interactions, and it facilitates R\&D collaboration, R\&D contracting, and hiring of local scientists and engineers. A large number of empirical studies has shown that proximity to, and involvement in, academic research, as well as collaborative research with academia, increases the innovative performance of firms (e.g., Acs, Audretsch, \& Feldman, 1991, 1994; Cassiman et al., 2008; Cockburn \& Henderson, 1998; Cohen et al., 2002; Fleming \& Sorenson, 2004; Gambardella, 1992; Jaffe, 1989; Leten, Landoni, \& Van Looy, 2014; Link et al., 2007; Mansfield, 1995; Zucker et al., 2002). Zucker et al. (2002) found that firms can improve their R\&D productivity by collaborating with academic "star" scientists in their fields of expertise. Empirical studies have, furthermore, shown that academic research stimulates the growth of industrial R\&D and the setup of new research-intensive ventures in the region (e.g., Anselin et al., 1997; Bania et al., 1992; Jaffe, 1989). Bania et al. (1992) showed that industrial R\&D laboratories in the United States were more likely to locate in metropolitan areas with university research as well as state supported science and technology programs. Zucker et al. (1998) demonstrated that the location of new biotech enterprises was closely related to the presence of "star" university scientists. Abramovsky et al. (2007) found that the presence of excellent university research departments in U.K. regions led to the expansion of industrial $R \& D$ activities in these regions. 
Despite the demonstrated importance of academic research linkages for industrial R\&D, studies of foreign R\&D locations by multinational firms have given little attention to the role of host countries' university research strengths. There is some prima facie evidence that this role is important, as the strength of local universities, and opportunities to collaborate with academia, rank high as factors determining the attractiveness of future foreign R\&D locations in surveys of multinational firms (Thursby \& Thursby, 2006). In addition, Florida (1997) reported that more than two-thirds of foreign-affiliated R\&D laboratories in the United States were collaborating with U.S. universities. Only a handful of empirical studies have examined the relationship between public research and foreign $\mathrm{R} \& \mathrm{D}$, but these have done so at an aggregate level or in a single country setting. Cantwell and Piscitello (2005) found a positive relationship between public R\&D employment and the aggregate R\&D activities of foreigncontrolled firms across European regions. Hegde and Hicks (2008) found a positive correlation between industry aggregates of U.S. multinational firms' foreign R\&D in host countries and host countries' and science and engineering publications. Alcacer and Chung (2007) demonstrated a positive influence of the local presence of patenting universities on foreign firms' propensity to locate FDI in U.S. regions, but their analysis was concerned with manufacturing rather than with R\&D activities. Belderbos, van Roy, Leten, and Thijs (2014) found a positive influence of academic research strength on foreign firms' R\&D investment location decisions for a sample of R\&D investments in European regions.

Even less is known about the role of corporate scientific research in increasing a location's attractiveness for (foreign) $R \& D$ investments. On the one hand, if firms engage in "open science" and contribute to local knowledge pools, this may increase local knowledge spillovers and increase agglomeration economies of R\&D. On the other hand, Furman et al. (2010) found that local firms' scientific research exhibits a negative correlation with innovative performance. They attribute this to the differential characteristics of corporate scientific research, which in general may be more applied in nature (e.g., Hicks, Ishizuka, Keen, \& Sweet, 1994; Lim, 2004), while new scientific insights due to corporate research are more likely to be covered by patents, limiting their use to other firms. In our analysis, we will contrast the effects of university scientific research and corporate scientific research.

\subsection{1 | Firm heterogeneity}

Prior studies have given relatively limited attention to the possibility that firms may react heterogeneously to the presence of academic research. The benefits of academic research are likely to differ across firms, as these possess different capacities to recognize, absorb, and utilize academic scientific knowledge (Cockburn \& Henderson, 1998; Cockburn, Henderson, \& Stern, 1999; Cohen \& Levinthal, 1990; Fabrizio, 2009; Gambardella, 1992; Liebeskind et al., 1996). Scientific research findings are not a free input to firms' own research activities. As Cohen and Levinthal (1990) have noted, learning is a cumulative, incremental process, which is influenced by capabilities that are already present at the individual and organizational level. The ability of organizations to learn from external research findings depends on the commonality of the organizations' internal knowledge base and the external research findings that firms intend to exploit in their technology activities (Teece, Pisano, \& Shuen, 1997). Hence, firms that want to take advantage of research conducted outside their organizations need to invest in an "absorptive capacity" in the sense of accumulating knowledge and skills to understand and utilize this externally generated knowledge (Cohen \& Levinthal, 1990). The creation of an absorptive capacity for external scientific knowledge involves the employment of a cadre of scientists, granting them resources, and providing the right organizational structures for the scientists to identify and absorb external scientific knowledge (Rosenberg, 1990; Pavitt, 1991). Employing scientists in-house (as "gatekeepers" and "boundary spanners") is important to establish a reputation in academia and to form a bridge with this scientific world (Allen, 1977; Cockburn \& Henderson, 1998; Liebeskind et al., 1996).

Hence, effectively drawing on the external science base is not costless but conditional on human capital within the firm as well as on the adoption of adequate organizational practices (Cockburn \& Henderson, 1998; Cockburn et al., 1999). The extent to which firms have been able to organize their R\&D activities in a way that they can draw on, and benefit from, external scientific developments is likely to be reflected in the degree to which their prior technology development activities have actually drawn on contributions to the scientific literature. We argue that firms with such a more outspoken science orientation in their prior $\mathrm{R} \& \mathrm{D}$ activities are more likely to benefit from academic scientific research, and are therefore likely to attach greater value to host countries' scientific research strengths in their foreign R\&D location choices.

We contrast this hypothesis on firms' science orientation with an alternative hypothesis that technology leadership is a main source of heterogeneity in R\&D location decisions (Alcacer, 2006; Alcacer \& Chung, 2007; Belderbos, Lykogianni, \& Veugelers, 2008a, 2008b; Shaver \& Flyer, 2000). Technologically leading firms may have a greater absorptive capacity for academic research in their technology field of specialization due to their experience in applied research and knowledge of the opportunities to use academic research in development activities. At the same time, technologically leading firms may be less 
attracted to locations with industrial R\&D due to concerns about outflows of knowledge and appropriability (Alcacer \& Chung, 2007; Shaver \& Flyer, 2000).

\section{3 | DATA, VARIABLES, AND EMPIRICAL METHOD}

We examine foreign R\&D location choices at the microlevel, using patent-derived information on new or extended R\&D activities at the technology field level (30 fields) for 175 R\&D intensive European, U.S., and Japanese multinational firms in the chemicals, pharmaceuticals, engineering, IT hardware, and electronics industries in 40 host countries for the periods 19951998 and 1999-2002. We infer R\&D locations from inventor information on EPO patent application documents and identified 277 cases where firms recorded substantive R\&D activities in particular technology fields in one of the host countries for the first time. This method necessitates the observation of patenting activities in multiple years in order to identify new R\&D activities with a sufficient degree of accuracy, as we will explain later. Our empirical strategy to isolate the effect of university research strength on R\&D location choices of firms is to utilize variation in host countries' relevant university research strength across the 30 technologies, while the time variation is limited to the two periods. In order to rule out potentially confounding effects of idiosyncratic country characteristics, the analyses include country fixed effects throughout. The main competing explanation for R\&D location decisions at the technology level is the attraction of concentrated industrial R\&D (patenting) activities in the host country. We measure technological strength at the country and technology level as the number of patents applied for in the field by host country inventors, and examine its relative explanatory power compared with university research strength.

\section{1 | Data and dependent variable}

We collected data on the location of technological activities of 175 high-technology firms in 40 host countries and 30 technology fields in two four-year periods (1995-1998 and 1999-2002). These firms are the most important R\&D spenders in their sectors and are roughly equally divided over home regions (Japan, Europe, and the United States) and five industries (engineering and general machinery, pharmaceuticals and biotechnology, chemicals, IT hardware, and electronics and electrical machinery). The "2004 EU Industrial R\&D Investment Scoreboard" was used to identify the sample firms: for each region (the United States, Japan, and Europe) the top 12 firms with the largest R\&D budgets in each of the industries were selected. ${ }^{2}$ The 175 firms were responsible for roughly 30\% of the European patent applications during the 1995-2002 period and spent on average 644 million U.S. dollar on R\&D in 2002. The smallest yearly R\&D budget amounted to 21 million dollars (Vaisala), and the largest reached almost 6 billion dollars (Pfizer). We note that our selection criteria imply a focus of analysis on technology intensive industries and relatively large firms. This focus is purposeful as this ensures that we observe significant numbers of cross-border R\&D activities. At the same time, we note that this focus limits the generalizability of our findings.

Two criteria were used to select the 40 host countries: (i) they record a minimum level of technological activity (50 patents) over the combined period 1995-2002 and (ii) data on country-level regressors (e.g., IPR protection, engineering wages) are available. The list of 40 host countries includes all major developed countries and the largest developing economies in SouthEast Asia and South America, plus South Africa (see Table I). The minimum number of patents ensures that host countries can be considered "at risk" of receiving R\&D investments, because patents invented in the host country are also used to identify foreign R\&D activities.

We use information on inventor addresses on patent documents to infer (new) locations of firms' R\&D activities. Patent data have the advantage of being easy to access, covering long time series and containing detailed information on the technological content, owners, and inventors of patented inventions. They also have shortcomings. For instance, not all inventions are patented and patent propensities vary across industries and firms (Basberg, 1987; Griliches, 1990), although this concern may be mitigated by the fact that patent propensities in the industries that we examine tend to be relatively high (Arundel \& Kabla, 1998). Given the novelty requirement for patents, patent-based indicators of foreign $R \& D$ are perhaps more likely to represent foreign research activities than foreign development activities directed at local adaptation. In the context of our research, a disadvantage is that patents are a form of "intermediate output" of the R\&D process rather than an input measure. Patent counts not only differ due to differences in the scale of R\&D operations, but also because of differences in R\&D productivity. Despite these drawbacks, patents are extensively used as indicator of the location of foreign inventive activities (Allred \& Park, 2007; Cantwell \& Piscitello, 2005; Guellec and Van Pottelsberghe, 2001; Le Bas \& Sierra, 2002; Patel \& Vega, 1999), given that systematic data (certainly at the firm level) on $R \& D$ expenditures by location are either not collected or not generally available for analysis. An additional advantage of the use of patent data relevant for our research is the detail that they provide on the different technological fields in which the patenting firms conduct $R \& D$. This allows for a more fine-grained analysis of the relationship between $R \& D$ 
T A B L E I Distribution of new foreign R\&D activities over countries and main technology fields

\begin{tabular}{|c|c|c|c|c|c|c|c|c|}
\hline \multirow[b]{2}{*}{ Country } & \multirow[b]{2}{*}{ 1995-1999 } & \multirow[b]{2}{*}{ 1999-2002 } & \multicolumn{5}{|l|}{ 1995-2002 } & \multirow{2}{*}{$\begin{array}{l}\text { 1995-2002 } \\
\text { New Entries }\end{array}$} \\
\hline & & & $\begin{array}{l}\text { Electrical } \\
\text { Engineering }\end{array}$ & Instruments & $\begin{array}{l}\text { Chemistry/ } \\
\text { Pharmaceuticals }\end{array}$ & $\begin{array}{l}\text { Process } \\
\text { Engineering }\end{array}$ & $\begin{array}{l}\text { Mechanical } \\
\text { Engineering }\end{array}$ & \\
\hline Argentina & 0 & 0 & 0 & 0 & 0 & 0 & 0 & 0 \\
\hline Australia & 2 & 0 & 0 & 1 & 1 & 0 & 0 & 2 \\
\hline Austria & 5 & 3 & 2 & 0 & 4 & 1 & 1 & 4 \\
\hline Belgium & 3 & 11 & 5 & 1 & 4 & 2 & 2 & 10 \\
\hline Brazil & 0 & 0 & 0 & 0 & 0 & 0 & 0 & 0 \\
\hline Canada & 4 & 15 & 12 & 2 & 2 & 2 & 1 & 11 \\
\hline China & 0 & 9 & 4 & 0 & 4 & 1 & 0 & 9 \\
\hline Colombia & 0 & 0 & 0 & 0 & 0 & 0 & 0 & 0 \\
\hline Denmark & 3 & 4 & 5 & 1 & 0 & 1 & 0 & 6 \\
\hline Finland & 4 & 2 & 3 & 0 & 1 & 1 & 1 & 6 \\
\hline France & 7 & 16 & 5 & 7 & 5 & 5 & 1 & 11 \\
\hline Germany & 9 & 14 & 10 & 2 & 4 & 2 & 5 & 11 \\
\hline Greece & 0 & 0 & 0 & 0 & 0 & 0 & 0 & 0 \\
\hline Hong Kong & 0 & 1 & 1 & 0 & 0 & 0 & 0 & 1 \\
\hline Hungary & 1 & 2 & 3 & 0 & 0 & 0 & 0 & 3 \\
\hline India & 1 & 1 & 1 & 0 & 1 & 0 & 0 & 2 \\
\hline Indonesia & 0 & 0 & 0 & 0 & 0 & 0 & 0 & 0 \\
\hline Ireland & 3 & 3 & 3 & 0 & 2 & 1 & 0 & 5 \\
\hline Israel & 4 & 3 & 4 & 2 & 0 & 1 & 0 & 5 \\
\hline Italy & 9 & 5 & 3 & 0 & 5 & 4 & 2 & 9 \\
\hline Japan & 7 & 18 & 5 & 5 & 7 & 7 & 1 & 16 \\
\hline Luxembourg & 0 & 0 & 0 & 0 & 0 & 0 & 0 & 0 \\
\hline Malaysia & 0 & 0 & 0 & 0 & 0 & 0 & 0 & 0 \\
\hline Mexico & 0 & 0 & 0 & 0 & 0 & 0 & 0 & 0 \\
\hline Netherlands & 6 & 9 & 2 & 4 & 7 & 2 & 0 & 5 \\
\hline Norway & 1 & 3 & 1 & 1 & 2 & 0 & 0 & 3 \\
\hline Philippines & 0 & 0 & 0 & 0 & 0 & 0 & 0 & 0 \\
\hline Poland & 0 & 1 & 1 & 0 & 0 & 0 & 0 & 1 \\
\hline Portugal & 0 & 0 & 0 & 0 & 0 & 0 & 0 & 0 \\
\hline Republic of Korea & 0 & 4 & 2 & 0 & 1 & 1 & 0 & 4 \\
\hline Russian Federation & 2 & 1 & 0 & 1 & 1 & 1 & 0 & 3 \\
\hline Singapore & 1 & 4 & 4 & 1 & 0 & 0 & 0 & 3 \\
\hline South Africa & 0 & 0 & 0 & 0 & 0 & 0 & 0 & 0 \\
\hline Spain & 0 & 5 & 3 & 2 & 0 & 0 & 0 & 2 \\
\hline Sweden & 4 & 6 & 7 & 0 & 1 & 1 & 1 & 8 \\
\hline Switzerland & 3 & 5 & 1 & 0 & 0 & 2 & 5 & 6 \\
\hline Taiwan & 0 & 1 & 1 & 0 & 0 & 0 & 0 & 1 \\
\hline Thailand & 0 & 0 & 0 & 0 & 0 & 0 & 0 & 0 \\
\hline United Kingdom & 8 & 13 & 7 & 3 & 4 & 1 & 6 & 8 \\
\hline United States & 18 & 13 & 9 & 8 & 4 & 7 & 3 & 14 \\
\hline Total & 105 & 172 & 104 & 41 & 60 & 43 & 29 & 169 \\
\hline
\end{tabular}

Note: New entries are those new R\&D activities in a country and technology field where the firm has no prior R\&D activities in other fields. 
location choices and academic strengths of host countries, as the latter also differ across science disciplines and related relevant technology fields. The patent data that we use in the current study are drawn from the EPO. We consider applications a more encompassing indicator of the presence of foreign R\&D activities than patent grants, as the latter exclude R\&D efforts and inventions that do not result in grants. ${ }^{3}$

We constructed patent data sets of firms at the consolidated level, that is, all patents of the parent firm and its consolidated (majority-owned) subsidiaries were retrieved. We used information on the addresses of the patent inventors to determine the country of origin of patented inventions, assuming that inventors live in the country of their workplace, or provide their workplace address in applications to the patent office. Inventor addresses give a much more accurate indication of patents' geographic origin than company addresses as firms tend to register the headquarter address with the patent office instead of the address of the subsidiary or unit where the invention originated as assignee address (Deyle \& Grupp, 2005; Khan \& Dernis, 2006). If a patent lists multiple inventors based in more than one country, we assigned the patent to each country. Finally, patents are assigned to technology fields based on their International Patent Class (IPC) technology codes and a technology concordance table that links each eight-digit IPC code (more than 64,000) to one of 30 technology fields. The concordance table has been jointly elaborated by Fraunhofer-Gesellschaft-ISI, Institut National de La Propriété Industrielle (INPI) and Observatoire de Sciences et des Techniques (OST) and combines IPC classes that represent similar technical functions or applications in broader technology fields. When a patent is assigned to different technology fields, it is counted in each of the fields.

We infer new R\&D activities abroad from information on the number of patent applications by each of the 175 firms in 30 technology fields, originating in 40 host countries. As our analysis seeks to establish whether there is an influence of host countries' academic research on R\&D location choices, we construct the dependent variable with the aim to measure the location of new R\&D activities. New R\&D activities and their locations are inferred from company patent data by applying two criteria. First, there are at least five patent applications by the firm in a country and field during a four-year time period. This threshold provides a reasonable assurance that we are measuring real $\mathrm{R} \& \mathrm{D}$ activity and that the patent data do not pick up the odd cases of expatriate company inventors mentioning their home address instead of the laboratory address. The four-year period helps to identify R\&D establishments that do not apply for patents in every year; it also allows for a time lag of (maximum) five years between R\&D investments and patent applications. ${ }^{4}$ Second, we require that the firm did not record any patent applications in the host country and technology field during the eight years prior to the observation period. ${ }^{5}$ Hence, we examine cases where the firm for the first time records substantial technology development activities in a host country and technology. This provides relatively strong assurances that existing R\&D activity is excluded and that we are examining first time $R \& D$ activities in the field. ${ }^{6}$ The dependent variable, $R \& D$ location choice, is constructed following this procedure for two subsequent four-year periods (1995-1998 and 1999-2002) and takes the value one if a firm records five patent applications in a host country and technology in which the firm did not record prior patent activities. Given the fine-grained analysis at the technology level, the occurrence of new $R \& D$ activities by a firm in a field and host country does not preclude that the firm is already active in $R \& D$ in a host countries in a different technology field. We control for such existing R\&D activities in the analysis. ${ }^{7}$

The twin criteria approach has a notable impact on the R\&D locations that we include in our analysis. If we would judge foreign R\&D locations simply from the presence of a single patent application by a firm in a host country and technology, the 175 sample firms record altogether more than 5,000 foreign R\&D activities at the combined host country-technology field level; in addition, all firms would have foreign R\&D activities. Application of the twin criteria reduces the number to just 277 locations for which we infer the presence of new substantive R\&D activities in one of the technology fields. This implies that on average, the firms in the sample recorded 1.5 new R\&D activities abroad over the two periods combined. Among the 175 firms, 83 have at least one new R\&D activity, and these firms on average recorded 3.3 new foreign $R \& D$ activities. The firms with new $R \& D$ activities have on average a similar science orientation as firms for which new $R \& D$ activities are not observed, and robustness analysis does not suggest the presence of sample selection bias. ${ }^{8}$

Table I shows the geographic distribution of the 277 cases over the 40 host countries and the main technology fields of the R\&D activities. Each of the 30 technology fields in the Fraunhofer/OST classification falls under the heading of one of five main technology fields: chemistry and pharmaceuticals, process engineering and special equipment, mechanical engineering and machinery, electrical engineering, and instruments. Table I shows that the largest number of new R\&D activities is recorded for the United States (31), followed by Japan (25), the large European countries (Germany, France, and the United Kingdom), and Canada. Particularly in the second period, new R\&D activities are also found in Asian countries such as China, South Korea, and Singapore. No new R\&D activities are recorded in Luxembourg and Portugal in Europe, the ASEAN countries except Singapore, the Latin American countries, and in South Africa. Table I also shows that the importance of the different main technology fields varies by country, with some countries recording a relatively high share of new R\&D activities in electrical engineering (such as Canada, Singapore, Denmark, and Hungary) and others in chemistry and pharmaceuticals (the Netherlands, Japan). R\&D activities focusing on instruments are relatively more frequent in France and the United States, mechanical engineering 
in Germany and Switzerland, and process engineering in Japan and Italy. The last column of Table I also shows that there are 169 cases of first-time R\&D activities by the firm in the particular host country, whereas there are 108 cases of R\&D extensions into new fields by firms that had prior R\&D activities in the host country in other technology fields.

\section{2 | Explanatory variables}

\subsection{1 | Host country university research strength}

The main explanatory variable of interest is university research strength. We use information on scientific articles with universityaffiliated authors published in peer-reviewed journals recorded in the Web of Science (WoS) publication database to assess the university research strengths of countries at the level of technology fields. Publications are extracted from yearly updates of the WoS database of Thomson Scientific and only papers of the document-type article, letter, note, and review have been selected. We measure the university research strengths of host countries in $t-1$ (years 1994 and 1998), and extracted all WoS publications (approximately 2 million) that were published in these years, which had at least one author's address in one of the 40 host countries.

Publications are classified in three categories, reflecting the type of organization to which authors are affiliated. We distinguish between universities, firms, and other institutions (individuals, government, hospitals, etc.). Publications can be assigned to multiple categories when different types of institutes are listed on the paper. The classification is made by processing information on authors' affiliations that are listed on publications. We classify the 200,000 different affiliations listed on the publications in two steps. First, we used search strings that contain keywords indicating universities or firms. The search string for universities contains keywords such as university, college, school, polytechnic, institute of technology, and their name variants in other countries. The search string for firms contains keywords that refer to legal forms in the various countries (such as incorporated, inc., $p l c, g m b h$, and many others). The remaining group includes individuals and all other institutions (government organizations, hospitals, and other nonprofit organizations). Second, we manually checked affiliations that were not classified by the search strings (giving priority to affiliations listed on multiple publications), until we could classify for each host country 95-99\% of the countries' publications. The results of this exercise showed that universities are listed on $76 \%$ of all the publications. The share of universities differs across countries, with low shares $(<60 \%)$ for the Philippines, Indonesia, India, and Hungary, and high shares (>90\%) for Singapore and Hong Kong. Firms are listed on 7\% of all the publications. Low shares of firm publications $(<1 \%)$ are found for Poland, Russia, China, and Portugal; high shares $(>10 \%)$ are observed for Switzerland, Denmark, and Japan. Based on the organizational classification of author affiliations, we calculated for each country the number of publications with university-affiliated authors at the level of 240 scientific disciplines. The scientific disciplines of publications can be determined by using information on the journals (and journal issues) in which publications are published and the ISI science classification table that assigns journal issues to one or more scientific disciplines (on average journals are assigned to 1.5 disciplines). The number of university publications relevant for each of the 30 technology fields is calculated by applying a detailed sciencetechnology concordance table. We use a concordance table (Van Looy et al., 2004) based on citation frequencies to publications in each of the 240 scientific disciplines as observed on patent documents classified in the different technology fields. This concordance attaches to each scientific discipline probabilities that it is of relevance to each technology field, and is based on citations to scientific articles in WoS covered journals $(500,000)$ that are found in more than 1 million granted United States Patent and Trademark Office (USPTO) and EPO patents filed between 1996 and 2001.

The variable university research strength of a country, measured at the technology field level, is the number of publications with university-affiliated authors in the country weighted by the probability that they are relevant to the technology field. As the WoS only includes journals that are peer-reviewed, adhere to standards of editorial policy, and have a threshold impact factor, the number of "relevant" university publications can be considered as a measure of the output of academic research of good quality. In addition to publications by university-affiliated authors, we also examine the role of scientific publication efforts by firms in attracting foreign R\&D: relevant publications with only firm-affiliated authors (corporate scientific research).

\subsection{2 | Other host country characteristics}

A reliable estimate of the role of countries' university research strengths in attracting foreign R\&D activities of firms requires controlling for other host country variables that may impact on foreign R\&D location choices of multinational firms. We include a broad set of host country factors that have been found to be relevant in previous empirical work, as reviewed in the theory section. In addition, we include a full set of host country fixed effects (alternative-specific constants) to control for unmeasured or unobserved time-invariant host country characteristics attracting firms' foreign R\&D activities. 
The most important control variable is the host country's technological strength in a field, measured by the number of patent applications originating in the host country in the technology field (30 fields). Further, the analysis takes into account the host country's level of IPR protection, by inclusion of the patent rights index from Park and Wagh (2002). This index is constructed based on five aspects of patent laws such as coverage, duration, and enforcement, ranging between 0 and 5, with high scores for IPR systems that are highly aligned with international standards. IPR data are available for the years 1995 (period 19951998) and 2000 (period 1999-2002). Both technological strength and IPR protection are expected to have a positive effect on multinational firms' R\&D location choices (e.g., Belderbos et al., 2008a, 2008b; Branstetter et al., 2006; Chung \& Alcacer, 2002). Countries with large and sophisticated markets, measured, respectively, by market size and GDP per capita levels, have also been found to attract foreign R\&D (e.g., Kuemmerle, 1999; Kumar, 2001; Shimizutani \& Todo, 2007). Market size is measured at the level of the main industry of the focal firm (due to data unavailability at the more detailed technology field level). It is defined as the sum of host country production and imports minus exports in the industry. Data are drawn from the OECD STAN database and UNIDO industrial yearbooks and are primarily defined at the ISIC two-digit level, distinguishing pharmaceuticals, chemical products, office machinery, electrical machinery, and machinery and equipment.

Locating R\&D activities in a host country is more likely when firms already have manufacturing or sales operations in the country, as manufacturing and sales operations call for product and process adaptations and adaptive R\&D (Kenney and Florida, 1994; Von Zedtwitz and Gassmann, 2002). We include a dummy variable (manufacturing or sales subsidiary) that takes the value one if a firm has at least one manufacturing or sales subsidiary in the host country. We draw on data from the early "Directories of Japanese Overseas Investments" published by Toyo Keizai for Japanese firms, and corporate annual reports and company web sites for European and U.S. firms. The likelihood that a host country attracts foreign R\&D will also be related to the geographic and language distance between the host and home country of the focal firm, as the cost of R\&D coordination and doing business abroad rises with distance (e.g., Belderbos et al., 2008a, 2008b; Nobel \& Birkinshaw, 1998). Geographic distance is measured in kilometers between the capital cities of both countries. Language similarity is a dummy variable that takes the value 1 if both countries share at least one official language. The wage costs of $R \& D$ personnel in the country is also expected to affect its attractiveness for inward foreign R\&D. Yearly gross income levels of engineers are taken as indicator of these wage costs. Data are taken from the UBS "Price and Earnings" reports, with 1994 wage levels assigned to period 1995-1998 and 1997 wage levels assigned to 1999-2002 (the closest year for which earnings reports were available). We prefer this variable to average (manufacturing) wage data drawn from other sources because we can expect that engineering wage levels are more representative of the wage levels of researchers to be employed for R\&D activities. We add a dummy variable for European host country to control for a potential propensity to patent bias in our data. Firms may be more likely to choose the EPO to apply for patent protection on inventions if these inventions originate in Europe, in particular if R\&D activities focus on applications of products and processes for the European market. The propensity to patent European-based inventions at the EPO may even be greater for European firms, because these are most likely to focus on the European market. Therefore, we also include a dummy variable, intra-European $R \& D$, taking the value one for European host countries in case the focal firm is based in Europe. In Section 4, we report on further robustness checks for the use of EPO data.

Finally, the analysis controls for the presence of existing R\&D activities of the firm in a host country. The variable existing $R \& D$ activities in other fields measures the extent to which firms conduct $R \& D$ activities in other technology fields in the host country. We infer the existence of such prior R\&D activities if the firm applied for five patents in technologies different from the focal field in a prior four-year period. We calculate existing $R \& D$ activities in other fields as the number of patent applications in this prior four-year period. In addition, the variable $R \& D$ experience in the host country measures the number of years since the first evidence of inventive activity by the firm in a host country, indicated by the year of filing of the firm's first patent with an inventor in the host country. Inclusion of these variables allows for experience and scope effects in local R\&D, which are likely to increase the probability that new R\&D activities are assigned to the host country. Together with the manufacturing or sales subsidiary dummy, these variables control for residual firm and host country unobserved heterogeneity prior to the period of analysis. All the continuous explanatory variables are taken in natural logarithms. One-year lagged values (1994 and 1998) are taken for all host country explanatory variables, except for the engineering wage and IPR protection levels, as discussed above.

\section{3 | Firm science orientation}

The presence of relevant academic research in host countries is expected to weigh more heavily for the R\&D location choices of firms with a more pronounced science orientation in prior $\mathrm{R} \& \mathrm{D}$ activities. The extent to which firms draw on academic knowledge depends partly on their technological focus, but also varies across firms active within similar technology fields. We measure a firm's science orientation through references to scientific literature in firms' prior patent applications. Surveys of patent inventors (Fleming \& Sorenson, 2004; Tijssen, 2001) have shown that inventors are aware of a significant part of the 
scientific papers cited in their patents, qualifying scientific nonpatent references as (imperfect) indicators of the "usage" of science by firms in their R\&D activities. Patents cite a variety of nonpatent literature (journals, books, newspapers, company reports, industry-related documents, etc.) that do not all refer to scientific sources (Callaert, Van Looy, Verbeek, Debackere, \& Thijs, 2006; Harhoff, Scherer, \& Vopel, 2003). In line with Fleming and Sorenson (2004) and Cassiman et al. (2008), we only consider nonpatent references to scientific journals listed in the WoS database as scientific references. We identified scientific nonpatent references by using an elaborate algorithm to link nonpatent references to ISI WoS journals. We included all 10,216 journals listed in the SCI between 1973 and 2006 and in the SSCI from 1986 to 2006. In order to get a more representative estimate of science citations, we examined three years of patent data of the firms prior to the investigation periods. We only use patents of inventions that are made in firms' home countries ( $80.5 \%$ of all patents of the sample firms) to avoid possible feedback effects from $R \& D$ activities abroad on the science orientation variable. The firms made 61,330 references to nonpatent literature in the two three-year periods of patent applications. Around half (48.9\%) of these nonpatent references cited WoS journals and were classified as scientific references. This number is comparable to those reported in prior studies on the nature of nonpatent references (Callaert et al., 2006; Harhoff et al., 2003; Narin \& Noma, 1985; Van Vianen et al., 1990). The variable firm science orientation is the average number of scientific references per patent in the firm's patent applications during the three years prior to the investigation period. The sample firms cited, on average, 0.4 scientific articles per patent, with values ranging from zero to five. The extent to which firms draw on scientific knowledge differs across industries but also varies substantially across firms within the same industry. Science orientation is, on average, highest for pharmaceuticals (average of 1.18) followed by the IT sector (average of 0.36), chemicals (average of 0.24), electronics (average of 0.18), and is the lowest for nonelectrical machinery (average of 0.07) At the same time, there are firms lacking a science orientation (zero references) in all five industries, while in each industry there are firms with high science orientation values (0.6-1.6). Descriptive statistics and correlations are relegated to the Appendix.

\section{4 | Empirical methods}

To examine the influence of university research strength on the location choice of new foreign R\&D activities in specific technology fields, we use a conditional logit model. Conditional logit models are commonly used in the literature to study the location choices of firms (Alcacer \& Chung, 2007; Chung \& Alcacer, 2002; Head, Ries, \& Swanson, 1995; Nachum et al., 2008). In the conditional logit model, characteristics of a potential choice (in this case: countries in which to locate new R\&D activities) determine its relative attractiveness and hence the probability that it is chosen for investment from among a set of alternatives. ${ }^{9}$ The choice set consists of all host countries with existing patenting activity in the field, ${ }^{10}$ with the exclusion of countries in which the firm is already active in the technology field, indicated by patent applications in a prior eight-year period. The functional form of the conditional logit model is given in equation (1):

$$
P_{i, f, c, t}=\frac{\exp \left(\mu_{c}+\alpha H_{f, c, t-1}+\beta H_{i, c, t-1}+\gamma H_{c, t-1}+\delta \gamma H_{c, s, t-1}\right)}{\sum_{c=1}^{Z} \exp \left(\mu_{c}+\alpha H_{f, c, t-1}+\beta H_{i, c, t-1}+\gamma H_{c, t-1}+\delta \gamma H_{c, s, t-1}\right)},
$$

where $P_{i, f, c, t}$ is the probability of firm $i$ in industry (sector) $s$ to locate new R\&D activities in technology field $f$ in country $c$ at time $t(t=1995-1998,1999-2002)$, rather than in any other country $c$ in the choice set $Z$. The independent variables include country fixed effects $\mu_{c}$, variables that vary over host countries and technology fields $\left(H_{f, c, t-1}\right.$ : university research strength, corporate scientific research, technological strength), variables that vary over firms and host countries $\left(H_{i, c, t-1}\right.$, e.g., language similarity, host country $R \& D$ experience), variables that vary over host countries $\left(H_{c, t-1}\right.$, such as GDP per capita, $I P R$ protection, engineering wage levels), and a variable varying over host countries and sector (market size, $H_{c, s, t-1}$ ).

In conditional logit models, chooser (firm) attributes are not included if these are not interacted with choice attributes: if chooser traits do not vary between countries, they cannot as such determine which country is chosen. Firm characteristics do have an impact on choices if they systematically alter the response to certain choice characteristics. We examine the moderating effect of such a firm characteristic — the science orientation of firms' R\&D—on host country attractors by conducting split sample tests around the sample median of the firm characteristic (cf. Alcacer \& Chung, 2007). A split sample analysis is the more general test specification when comparing coefficients between groups of observations, that is, firms (Hoetker, 2007). A split sample test does not assume that the unexplained variance is identical between groups of firms and allows for the influence of other country characteristics to differ systematically between the groups, ensuring consistent within-group estimates. ${ }^{11}$ We cluster error terms by firm to control for correlations in error terms due to unobserved firm traits favoring certain locations over others. 
As the (continuous) explanatory variables are included in logarithmic form, this implies that the estimated coefficients of the host country variables have a direct interpretation as indicators of the importance of these variables in attracting foreign $R \& D$ activities. The average elasticity of the probability of location choice with respect to a logarithmic transformed variable is calculated as $(Z-1) / Z$ times the coefficient of the variable, where $Z$ is the total number of choices (Greene, 2003, p. 723; Head et al. 1995, p. 237). In our model, there is a maximum of 39 choices. Due to the exclusion from the choice set of countrytechnology pairs for which no host country patents were recorded, or in which firms had existing R\&D activity in specific technology fields, the average number of choices is close to just above 32. With choice sets of this size, the estimated coefficients approximate the average elasticities.

\section{I EMPIRICAL RESULTS}

The results of the conditional logit analyses are reported in Table II. We first estimate models on the full sample for comparison, and subsequently estimate models separately for firms with an above median ("high") science orientation and firms with a below median ("low") science orientation. The sample split is based on the median science orientation in each observation period.

In the full sample model (model 1), the university research strength variable has a positive and significant coefficient, confirming that firms take countries' university research strengths relevant to their technology field into account in their foreign R\&D location choices. The coefficient implies an average elasticity of about 0.95: a doubling in relevant university research strength increases the probability that a country is chosen as the location of new R\&D activities by $95 \%$. Corporate scientific research, on the other hand, has a negative sign but is not significantly different from zero. Host countries' technological strength in the technology field and relevant market size also have significantly positive coefficients. The estimated coefficient on technological strength implies an elasticity of about 0.23 - substantially smaller than the elasticity of university research strength.

For variables that vary only by host country and not by firm, industry, or technology (IPR protection, GDP per capita, engineering wage), no significant coefficients are estimated. This may be explained by their limited variation: given the inclusion of host country fixed effects, identification of host county effects has to rely on only two observations, one for each time period. The significant coefficient of language similarity shows that firms are more likely to locate foreign R\&D activities in countries that share a similar language with their home country. There is no further significant effect of geographic distance between home and host countries. The variables controlling for potential differences in the propensity to patent by European firms and for European inventions by European firms are not significant either, indicating that there is no apparent systematic bias in the location analysis stemming from the use of EPO data. All firm-specific host country control variables are positive and significant, indicating that locations where firms have prior manufacturing or sales affiliates, R\&D activities in other technology fields, and a longer history of inventive activity are more likely to attract new R\&D activities.

The second and third columns in Table II report coefficients of the same specification, but then for the two subsamples of firms with high and low science orientation. In the high science orientation subsample, the variable university research strength is again highly significant and larger than in the full sample model, implying an average elasticity of about 1.50 . In contrast, for the low science orientation subsample, the university research strength variable is not significantly different from zero. The coefficient of corporate scientific research is insignificant in both subsamples. Technological strength loses its significance in both subsamples, which may be due to the reduction in degrees of freedom in subsample analysis. Other observations are that the $R \& D$ location choices of less science-oriented firms are more strongly related to firms' earlier R\&D experience in a country, while location decisions by firms with higher science orientation are more driven by the presence of prior manufacturing or sales subsidiaries. A possible explanation for this pattern is that new R\&D activities of the former firms are more of an incremental nature, building on existing $R \& D$ activities, whereas $R \& D$ entries by firms with a high science orientation focus relatively more on independent research activities. The counterintuitive weakly significant positive coefficient of engineering wage in the low science orientation subsample may perhaps indicate that wages are correlated with the quality of human capital, for which the analysis cannot sufficiently control.

The results reported in Table II are consistent with the notion that relevant university research strengths play a role in multinational firms' foreign R\&D location choices, but that firms are heterogeneous in the weight they give to countries' academic research in these choices. Firms do not value corporate scientific research activities in host countries as an additional factor in their foreign R\&D location choices. ${ }^{12}$

A possible alternative hypothesis related to firm heterogeneity in $R \& D$ location choices is that such heterogeneity stems from firms' technological strength. Technologically leading firms may have a greater absorptive capacity for knowledge stemming from academic research and at the same time, they may be less attracted to locations with industrial R\&D due to concerns about outflows of knowledge and appropriability (Alcacer \& Chung, 2007). We examined potential systematic differences in 
T A B L E I I Foreign R\&D location choice and scientific research strengths

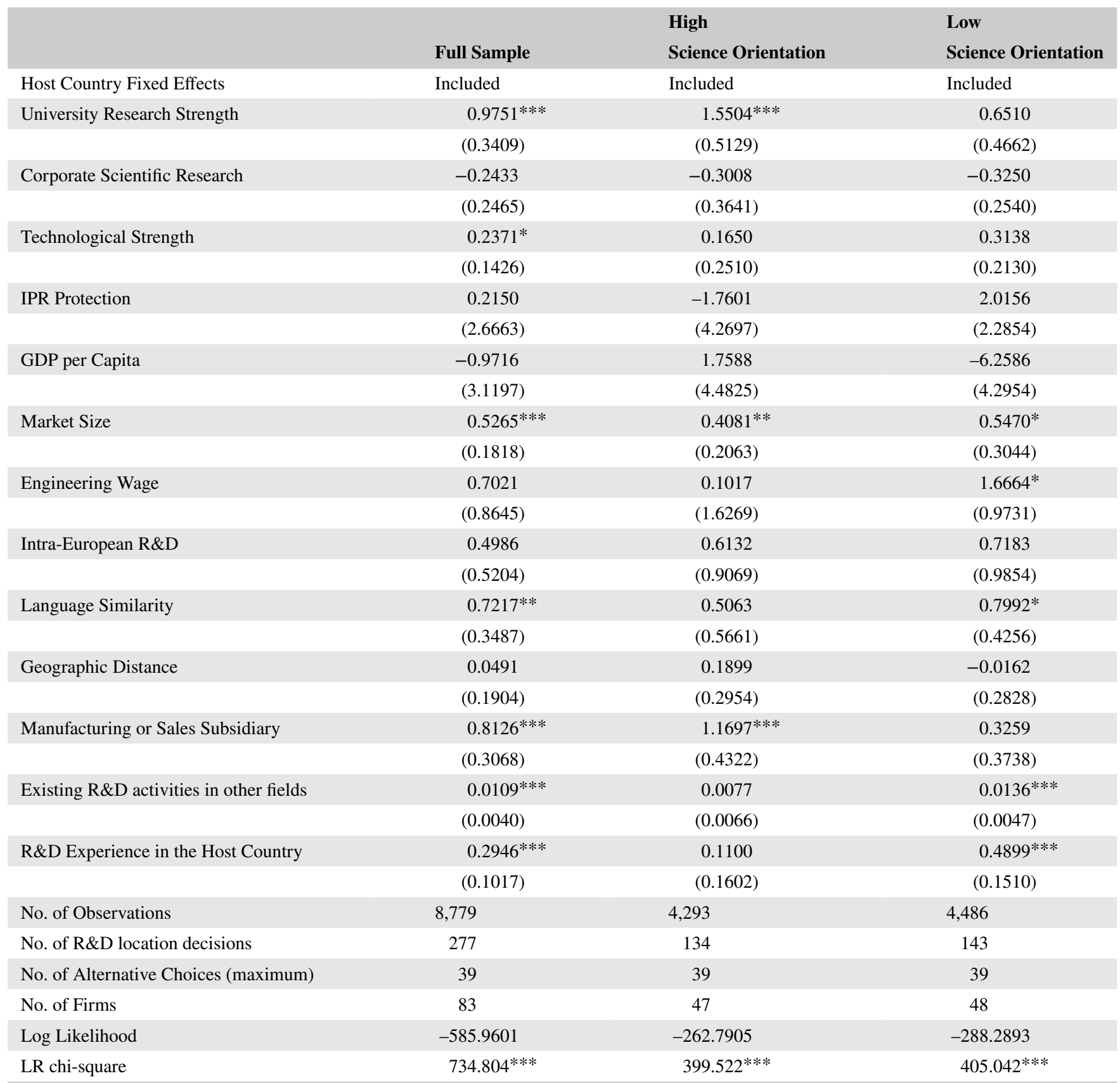

Note: Estimation results of conditional logit models; robust standard errors, clustered by parent firm, in parentheses.

$* * *, * *$, and $*$ indicate significance at the $1 \%, 5 \%$, and $10 \%$ level, respectively.

the drivers of R\&D location choices between technology leaders and laggards by performing a split sample test at the median worldwide share of patents of the firm in the respective technology field. In order to test whether science orientation or technology leadership is the main source of firm heterogeneity affecting the response to university research strength, we further distinguished subsamples of high science orientation firms and low science orientation firms for both technology leaders and technology laggards, which results in four subsamples of observations. The results of the four models are presented in Table III. They confirm the dominant role of firms' science orientation. Both for technology leaders and technology laggards, the subsamples of high science orientation firms show a significant effect of university research. The results suggest that it is heterogeneity due to science orientation rather than an independent influence of technology leadership that matters for the influence of university research strength on R\&D location decisions. At the same time, we observe that within the group of high science-oriented firms, the coefficient on university research is substantially larger for technology laggards than for technology leaders-with the 
T A B L E I I I Foreign R\&D location choice and firm heterogeneity: technology leadership versus science orientation

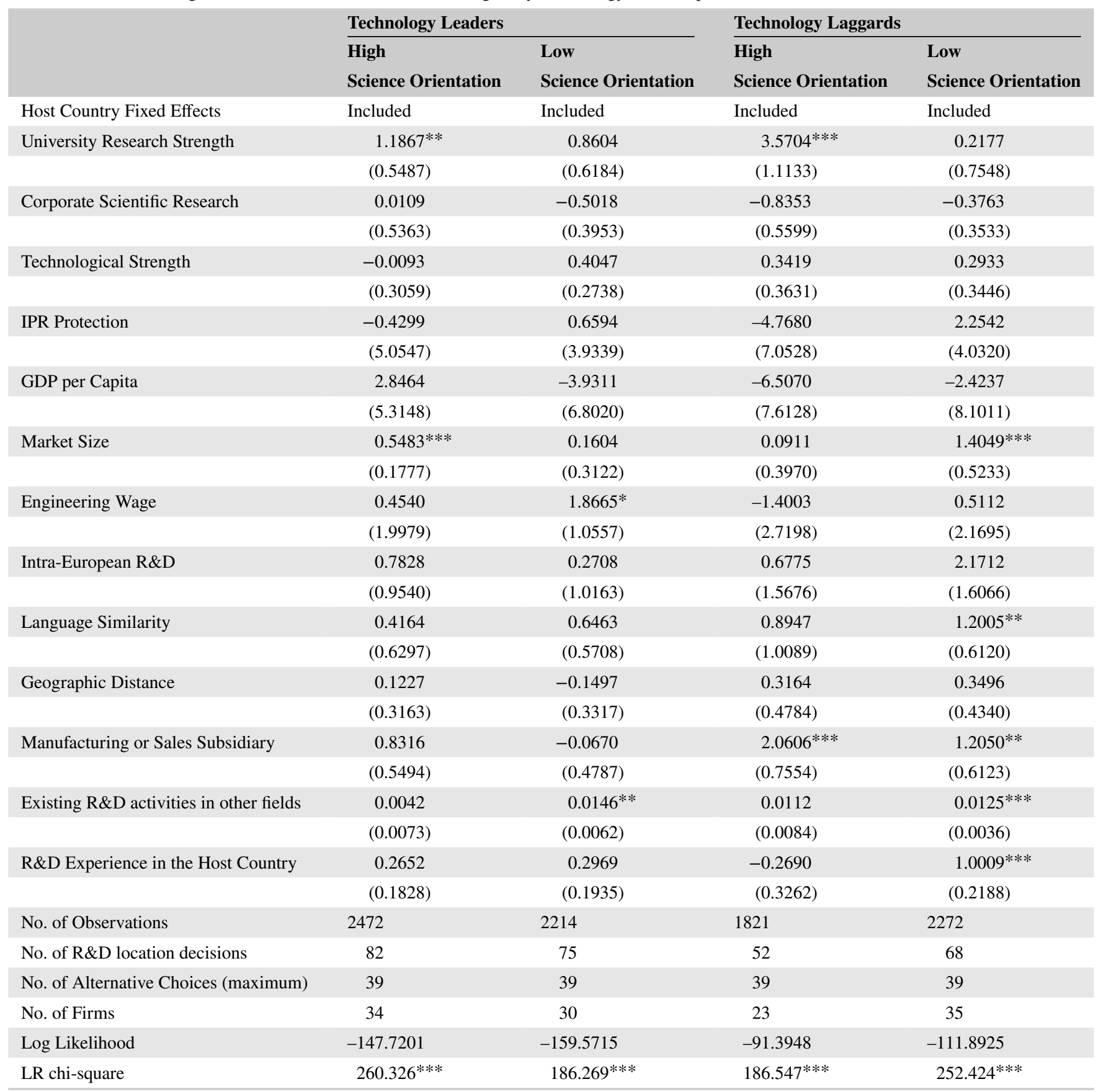

Note: Estimation results of conditional logit models; robust standard errors, clustered by parent firm, in parentheses.

$* * *, * *$, and $*$ indicate significance at the $1 \%, 5 \%$, and $10 \%$ level, respectively.

difference statistically significant $(z=2.05, p=0.041)$. One explanation for this pattern is that among science-oriented firms, access to university research is a particular way to catch up for technology laggards.

\section{1 | Supplementary analyses}

We conducted a number of sensitivity tests to examine the robustness of the empirical results. One important robustness test relates to the country level of our analysis. The country-level analysis can be considered a relatively crude way to identify the potential attraction of academic research, in particular in larger countries. Prior studies have suggested that knowledge flows are positively related to geographic proximity (Anselin et al., 1997; Belenzon and Schankerman, 2012; Jaffe, 1989)—although there is also evidence that firms value quality of research over proximity (Laursen, Reichstein, \& Salter, 2011; Okamuro \& 
T A B L E I V Foreign R\&D location choice and scientific research strengths: regional level analysis

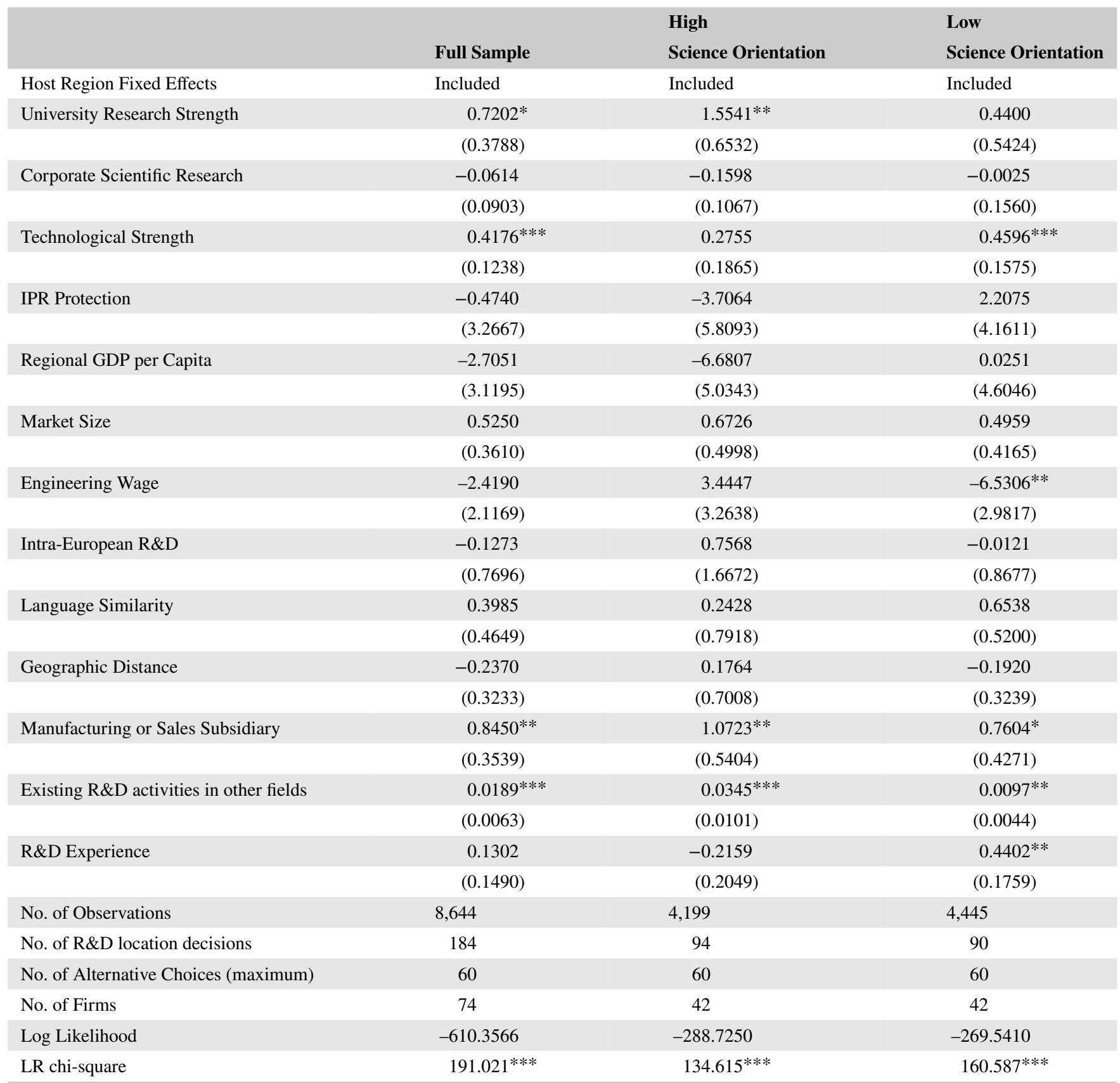

Note: Estimation results of conditional logit models; robust standard errors, clustered by parent firm, in parentheses.

$* * *, * *$, and $*$ indicate significance at the $1 \%, 5 \%$, and $10 \%$ level, respectively. The choice set includes U.S. states, European NUTS-1 regions, and Japanese prefectures.

Nishimura, 2013). The importance of proximity may imply that relevant academic strength is overestimated in country-level analyses, because it captures all academic research activity in a country, while firms are most likely to benefit from university research that is located sufficiently proximate to their R\&D establishments. Our empirical models at the country level assume that all academic research is "within reach" and concentrated near the location of corporate R\&D activities, or alternatively, that there is no strong difference in academic specialization across regions within a country, such that differences across countries at the aggregate level are representative of differences across regions at a more fine grained spatial level.

We examined the robustness of the empirical results to changing the geographic level of analysis by conducting an R\&D location analysis at the regional level. Regional data could be made available for the three major R\&D locations in our sample: the United States (state level), Europe (NUTS-1 regions) and Japan (prefectures). In this setup, we could include 184 of the set of 277 identified new R\&D activities. The regions with the largest number of new R\&D activity cases are California, mainland 
Finland, and the Northwest of Italy. The choice set consists of 154 regions of which 60 have received at least one new R\&D activity.

There were a number of hurdles to take before regional location analysis at this global level could be conducted. The lack of representative and comparable regional-level indicators and controls (e.g., market size, wage of engineers), does not allow replicating a full-fledged country model at the regional level with region-specific regressors. Hence, we estimate conditional logit models with regional fixed effects. In addition, we substituted GDP per capita by its regional equivalent, as GDP per capita is one of the few variables that are readily available and comparable across regions globally. We regionalized the university strength and corporate scientific research variables by identifying regions from address information on publication documents. We regionalized patent data based on the OECD REGPAT database: for the technological strength variable as well as for the dependent variable. The variables "other R\&D activities" and "prior R\&D experience" were also consistently redefined at the regional level.

Results of the conditional logit analysis of the regional choice for the 184 new R\&D activities are shown in Table IV. In the full sample model, university strength has a (weakly) significant coefficient of 0.72 : slightly lower than in the country model of Table II. For the subsample of firms with a high science orientation, the coefficient increases to 1.55—almost identical to the estimated coefficient in the country model (Table II) for the same subset of firms. For the subsample of firms with low science orientation, the coefficient of university research strength is again insignificant. Regional technological strength has a significant influence on regional R\&D locations both in the full sample and in the low science orientation subsample, but not in the high science orientation subsample. This is intuitive, because firms with a weaker science orientation are more likely to draw more intensively on industrial R\&D (other firms' patents) in their technology development. The overall stronger effects of technological strength may be due to greater specialization across regions within a country for industrial R\&D activities, which may make a regional-level analysis relatively more appropriate to identify the role of relevant technological strength. Among the other variables, prior (R\&D) activities of the firm in the region generally have a strong influence on location choice, and higher wage costs discourage R\&D investments in the low science orientation subsample. Overall, the empirical results are consistent with the results obtained from the country model.

A second concern we addressed is potential selection bias stemming from the inclusion of only a subset of the 175 sample firms in our location analyses. We estimated models in which most of the sample firms are retained by applying a less strict criterion to establish new R\&D activities: that is, all cases where firms record a minimum of one patent application in a field and host country for the first time. This analysis included 4,001 "entries" by virtually all (171 of 175 firms) sample firms. Although coefficients on university research strength were substantially smaller due to this lower threshold, an identical pattern of coefficients was observed, with a significant effect for high science-oriented firms but no significant influence on R\&D location decisions of firms with a lower science orientation.

Finally, we explored models with extended sets of fixed effects, including sets of combined dummies for host country-period, host country-technology field, and host country-home country, respectively. The core results were surprisingly consistent under these circumstances. Hence, it appears that the identification of the effect of academic research strength derives from both variation across technology fields and variation within technology fields over time, while controlling for investment propensities at the bilateral level (host-home country) does not substantially affect inference.

\section{I CONCLUSION AND DISCUSSION}

In this paper, we examined to what extent the scientific research strengths of (potential) host countries affect the probability of multinational firms to locate R\&D activities in these countries. We also explored whether there is firm heterogeneity in the responses to host countries' strengths of relevant academic research. We posited that firms possess different capacities to recognize, absorb, and utilize academic knowledge, depending on the science orientation of their R\&D activities. We examined foreign R\&D location choices at the microlevel, using data on the location of patented inventions at the technology field level (30 fields) for 175 R\&D intensive European, American, and Japanese firms in 40 host countries, during 1995-1998 and 19992002. Inferring new $R \& D$ activities abroad from inventor information on patent documents, we identified 277 cases in which firms recorded R\&D activities in particular technology fields in one of the host countries for the first time. We measured the strength of scientific research in host countries at the level of technology fields by counting publications of authors with host country university (university research strength) or firm (corporate scientific research) affiliations in scientific disciplines that are relevant to the specific technology fields. As indicator of the science orientation of firms' research activities, we calculated the frequency of citations to scientific literature on firms' prior patent applications originating in their home countries. 
We find that the probability to locate R\&D in a host country is on average positively affected by the host country's university research strength, after controlling for host country fixed effects and other host country characteristics that attract or discourage inward R\&D. The analysis reveals substantial firm heterogeneity in the importance attached to university research in foreign R\&D location choices. Firms with a relatively strong (above median) science orientation in their R\&D activities respond strongly to host country academic research, whereas for firms with a weaker (below median) science orientation, university research strength has no significant influence on $R \& D$ location choices. These results are robust across a number of alternative specifications, including analysis at the regional level and analysis using a different measurement of R\&D activities. The magnitude of the impact of host countries' university research strength on the R\&D location choices of firms is substantial, with estimated elasticities ranging between 1.5 and 3.5 for firms with a strong science orientation.

Our results clearly demonstrate the importance of taking into account relevant aspects of firm heterogeneity when analyzing firms' location choices (Alcacer, 2006; Alcacer \& Chung, 2007; Nachum et al., 2008), and support the notion that firms' science orientation is a key exponent of such heterogeneity. If we contrast science orientation with technology leadership as an alternative form of firm heterogeneity affecting location decisions (e.g., Alcacer \& Chung, 2007) we find that technology leadership does not increase firms' responsiveness to academic research in foreign R\&D location choices. Rather, it is the group of technology laggards among firms with a high science orientation that is most responsive to academic research, perhaps because access to university research is a particular way to catch up with technology leaders.

We find that university research strength matters for R\&D location choices, but that firms are not responding to host countries' corporate scientific research strengths. One explanation is that corporate scientific research may generate fewer spillovers as research outcomes are more likely to be protected by patents, limiting their use to other firms (e.g., Furman et al., 2010), while incumbent firms will also compete with entrants for qualified engineers. Another explanation for the differential effect of pure academic and corporate scientific research strengths on firms' $R \& D$ location choices may be that universities and firms focus on a different type of scientific research. Universities are likely to conduct scientific research that is more "basic" in nature than the scientific research conducted by firms. Although the outcomes of applied scientific research may have direct commercial applications, basic scientific research may generate insights and ideas that have stronger (although more long-term) effects on the efficiency of the technology activities of firms that absorb and exploit basic scientific research findings (Fleming \& Sorenson, 2004; Rosenberg, 1990). Future research could investigate which type of scientific research is valued most by firms in their R\&D location choices, by differentiating publications and journals by the degree of "basicness" (e.g., Lim 2004).

Our research contributes to the literature on location choices by multinational firms. First, we suggest that knowledge sourcing from universities is an important motivation for international R\&D location decisions, and that firms that locate in host countries with strong academic capabilities effectively draw on local scientific knowledge. Second, we show that in this context a key source of heterogeneity that has not been considered in previous studies is firms' science orientation and capacity to draw on scientific knowledge in their R\&D and technology development activities. These two related findings have implications for the literature on R\&D internationalization and performance (e.g.,Griffith et al. 2008; Lahiri, 2010; Singh, 2008; Todo \& Shimizutani, 2008). Although a number of prior studies have taken host countries' technological strength into account in predicting positive performance effects of geographic dispersion of $R \& D$, university research strength and knowledge sourcing from universities has not been taken into consideration. Future research could explore whether, conditional on the science orientation of firms $R \& D$ activities, locating new $R \& D$ activities in countries with strong relevant academic scientific capabilities holds the promise of improving technological performance.

Taken together, our findings are consistent with the premise that policies to strengthen university research can be effective in attracting R\&D activities of multinational firms. We emphasize, however, that our findings should not be taken to suggest that publication output itself is creating this attraction to foreign firms' R\&D. Rather, the presence of a critical mass of academic research, as indicated by publication output in peer reviewed journals, proxies for opportunities of firms to link up to strong local scientific networks of university researchers, collaborate with university research groups and university spinoffs, or hire capable doctoral researchers from these universities. A limitation of our study is that we cannot distinguish between all these different mechanisms of industry-university linkages in detail. Further research should aim to disentangle the industry science knowledge transfer mechanisms and the university characteristics that are most effective in attracting foreign R\&D.

Future research could also address other limitations of our study: the use of patent data to identify new R\&D activities abroad and the focus on large firms in technology intensive industries. The reliance on patent data to infer R\&D activities necessarily suffers from a number of imperfections. Although validity checks and alternative specifications did not suggest that this reduced the reliability of our estimates, analysis of R\&D expenditure data by firms at the country and technology (or industry) level would have obvious advantages. We do hope that future empirical work could investigate R\&D location and allocation patterns by using alternative data sources measuring foreign $R \& D$ activities and by expanding analysis to smaller firms in a broader set of industries. 


\section{NOTES}

${ }^{1}$ There are a number of partial exceptions suggesting that academic research may be of importance to the presence of foreign R\&D. These have, however, focused on foreign R\&D at the aggregate industry level (Cantwell \& Piscitello, 2005; Hegde \& Hicks, 2008), on differences in foreign (manufacturing) presence across regions in a single host country (Abramovsky et al., 2007; Alcacer and Chung, 2007), or on R\&D investments confined to European regions (Belderbos et al., 2014).

${ }^{2} \mathrm{~A}$ few of these firms dropped out because they experienced major mergers during the period, which hampered systematic analysis.

${ }^{3}$ The patent grant rate at the EPO is 59\% (Van Pottelsberghe de la Potterie, 2007).

${ }^{4}$ Prior work at the consolidated firm level has suggested that R\&D to patent application lags are on average two years (Hall, Griliches, \& Hausman, 1983). A five-year maximum lag appears conservative against this background.

${ }^{5}$ We limit the window of no inventive activity to eight years because going back further would render our consolidation exercise at the firm level less representative.

${ }^{6}$ In a partial validity analysis comparing the R\&D locations with published information on Japanese firms' (R\&D conducting) affiliates, we found broad confirmation that the dependent variable reflects the presence of actual R\&D activities of the firms.

${ }^{7}$ One possible concern is that the number of patents applied for in the host country by the investing firm is itself influenced by the university strength in the host country due to potential positive spillover effects, creating a spurious correlation between the two measures. We examined this issue in detail through an auxiliary analysis of the determinants of postentry patent counts. Although technological strength of the firm and the host country were significant drivers, host country university strength was not. This is likely to be related to the relatively long lags with which university research is translated into patented research. Further analysis of the characteristics of patents due to new R\&D activities showed that, in host countries with substantial university strengths, patents tended to cite local university publications, while the average citation lag was 5.5 years.

${ }^{8}$ The average science orientation in the group of 83 firms with new R\&D activities is 0.38 , compared with an average value of 0.41 for the group of 92 firms without new R\&D activities. The mean difference is 0.032 and the $t$-statistic is 0.51 that implies a $p$-value of 0.6 . We discuss concerns related to potential sample selection bias in the supplementary analysis section.

${ }^{9}$ Belderbos (1992) and Belderbos, Fukao, Ito, and Letterie (2013) derive the role of relative locational utility in international investment allocation models.

${ }^{10}$ The exclusion of specific country-technology pairs for which no patent activity is recorded primarily occurs in countries with limited overall patenting activity (such as Luxemburg, the Philippines, Indonesia, and Columbia). These cases are excluded because the absence of local patents directly implies the absence of new R\&D activities measured through patent data, creating a tautological relationship between technological strength and entry.

${ }^{11}$ Allowing coefficients of other variables to vary between firms with high and low science orientation has practical empirical relevance. The coefficients on the control variables in the two subsamples are jointly significantly different, and the bias introduced by restricting the coefficients to be equal (e.g., by only estimating one interaction term between university strength and firm science orientation) hampers identification of the differential influence of university strength. Estimating a single interaction term produced a positive but insignificant coefficient.

${ }^{12}$ We observed that the insignificance of corporate scientific research remains even if technological strength is omitted from the model.

\section{RE FERENCES}

Abramovsky, L., Harrison, R., \& Simpson, H. (2007). University research and the location of business R\&D. Economic Journal, 117(519), C114C141.

Acs, Z., Audretsch, D., \& Feldman, M. (1991). Real effects of academic research: Comment. American Economic Review, 81, $363-367$.

Acs, Z., Audretsch, D., \& Feldman, M. (1994). R\&D spillovers and recipient firm size. The Review of Economics and Statistics, 76, 336-340.

Alcacer, J. (2006). Location choices across the value chain: How activity and capability influence collocation. Management Science, 52(10), $1457-1471$.

Alcacer, J., \& Chung, W. (2007). Location strategies and knowledge spillovers. Management Science, 53(5), 760-776.

Allen, T. (1977). Managing the flow of technology. Cambridge, MA: MIT Press.

Allred, B., \& Park, W. (2007). Patent rights and innovative activity: Evidence from national and firm-level data. Journal of International Business Studies, 38, 878-900.

Ambos, B. (2005). Foreign direct investment in industrial research and development: A study of German MNCs. Research Policy, 34(4), 395-410.

Ambos, B., \& Ambos, T. C. (2011). Meeting the challenge of offshoring R\&D: An examination of firm- and location-specific factors. R\&D Management, 41(2), 107-119.

Anselin, L., Varga, A., \& Acs, Z. (1997). Local geographic spillovers between university research and high technology innovations. Journal of Urban Economics, 42, 422-448.

Arundel, A., \& Kabla, I. (1998). What percentage of innovations are patented? Empirical estimates from European firms. Research Policy, $27,127-141$. 
Bania, N., Calkins, L., \& Dalenberg, R. (1992). The effects of regional science and technology policy on the geographic distribution of industrial R\&D laboratories. Journal of Regional Science, 32, 209-228.

Basberg, B. (1987). Patents and the measurement of technological change: A survey of the literature. Research Policy, 16, $131-141$.

Belderbos, R. (1992). Large multinational enterprises based in a small economy: Effects on domestic investment, Weltwirtschaftliches Archiv, 128, 543-557.

Belderbos, R. (2003). Entry mode, organizational learning, and R\&D in foreign affiliates: Evidence from Japanese firms. Strategic Management Journal, 24(3), 235-259.

Belderbos, R., Fukao, K., Ito, K., \& Letterie, W. (2013). Global fixed capital investments by multinational firms. Economica, 80(318), $274-299$.

Belderbos, R., Lykogianni, E., \& Veugelers, R. (2008a). Strategic R\&D location by multinational firms: Spillovers, technology sourcing, and competition. Journal of Economics and Management Strategy, 17(3), 759-779.

Belderbos, R., Lykogianni, E., \& Veugelers, R. (2008b). Strategic R\&D location in European manufacturing industries. Review of World Economics, 14(2), 1-24.

Belderbos, R., van Roy, V., Leten, B., \& Thijs, B. (2014). Academic research strengths and multinational firms' foreign R\&D location decisions: Evidence from foreign R\&D projects in European regions. Environment and Planning A, 46(4), 920-942.

Belenzon, S., \& Schankerman, M. (2012). Spreading the word: geography, policy, and knowledge spillovers. Review of Economics and Statistics, 85, 884-903.

Berry, H. (2006). Leaders, laggards, and the pursuit of foreign knowledge. Strategic Management Journal, 27, 151-168.

Bonaccorsi, A., Colombo, M. G., Guerini, M., \& Rossi-Lamastra, C. (2013). The impact of local and external university knowledge on the creation of knowledge-intensive firms: Evidence from the Italian case. Small Business Economics, 43, 1-27.

Booz Allen Hamilton and INSEAD (2006). Innovation: Global the way forward? Fontainebleau, Paris: INSEAD.

Branstetter, L., Fisman, R., \& Foley, C. F. (2006). Do stronger intellectual property rights increase international knowledge transfer? Empirical evidence from U.S. firm-level panel data. Quarterly Journal of Economics, 121(1), 321-349.

Callaert, J., Van Looy, B., Verbeek, A., Debackere, K., \& Thijs, B. (2006). Traces of prior art: An analysis of non-patent references found in patent documents. Scientometrics, 69(1), 3-20.

Cantwell, J., \& Mudambi, R. (2005). MNE competence-creating subsidiary mandates. Strategic Management Journal, 26(12), 1109-1128.

Cantwell, J., \& Piscitello, L. (2005). Recent location of foreign-owned research and development activities by large multinational corporations in the European regions: The role of spillovers and externalities. Regional Studies, 39, 1-16.

Cassiman, B., Veugelers, R., \& Zuniga, P. (2008). In search of performance effects of (in) direct industry science links. Industrial and Corporate Change, 17(4), 611-646.

Chung, W., \& Alcacer, J. (2002). Knowledge seeking and location choice of foreign direct investment in the United States. Management Science, 48(12), 1534-1554.

Chung, W., \& Song, J. Y. (2004). Sequential investment, firm motives, and agglomeration of Japanese electronics firms in the United States. Journal of Economics and Management Strategy, 13(3), 539-560.

Cockburn, I., \& Henderson, R. (1998). Absorptive capacity, co-authoring behaviour, and the organization of research in drug discovery. Journal of Industrial Economics, 46(2), 157-182.

Cockburn, I., Henderson, R., \& Stern, S. (1999). The diffusion of science-driven drug discovery: Organizational change in pharmaceutical research. NBER Working paper no. 7359, National Bureau of Economic Research Inc.

Cohen, W., \& Levinthal, D. (1990). Absorptive capacity: A new perspective on learning and innovation. Administrative Science Quarterly, 35, $128-152$.

Cohen, W., Nelson, R., \& Walsh, J. (2002). Links and impacts: The influence of public research on industrial R\&D. Management Science, 48(1), 1-23.

Criscuolo, P., Narula, R., \& Verspagen, B. (2005). The role of home and host country innovation systems in R\&D internationalization: A patent citation analysis. Economics of Innovation and New Technologies, 14(5), 417-433.

Deyle, H., \& Grupp, H. (2005). Commuters and the regional assignment of innovative activities: A methodological patent study of German districts. Research Policy, 34, 221-234.

Driffield, N., Love, J. H., \& Menghinello, S. (2010). The multinational enterprise as a source of international knowledge flows: Direct evidence from Italy. Journal of International Business Studies, 41, 350-359.

Fabrizio, K. (2009). Absorptive capacity and the search for innovation. Research Policy, 38(2), 255-267.

Fleming, L., \& Sorenson, O. (2004). Science as a map in technological search. Strategic Management Journal, 25, 909-928.

Florida, R. (1997). The globalization of R\&D: Results of a survey of foreign-affiliated R\&D laboratories in the USA. Research Policy, $26,85-103$.

Fors, G. (1997). Utilization of R\&D results in the home and foreign plants of multinationals. Journal of Industrial Economics, 45(3), $341-358$.

Frost, T. (2001). The geographic sources of foreign subsidiaries' innovation. Strategic Management Journal, 22, 101-124.

Frost and Sullivan (2004). Outsourcing technology in Asia: Analysis of the changing face of $R \& D$. San Antonio, TX: Frost and Sullivan Company. 
Furman, J. L. (2003). Location and organizing strategy: Exploring the influence of location on the organization of pharmaceutical research. Advances in Strategic Management, 20, 49-87.

Furman, J., Kyle, M., Cockburn, I., \& Henderson, R. (2010). Public and private spillovers, location and the productivity of pharmaceutical research. Annales d'Economie et de Statistique, 79/80, 167-190.

Furman, J., \& MacGarvie, M. (2007). Academic science and the birth of industrial research laboratories in the U.S. pharmaceutical industry. Journal of Economic Behavior and Organization, 63(4), 756-776.

Gambardella, A. (1992). Competitive advantages from in-house scientific research: The US pharmaceutical industry in the 1980s. Research Policy, $21,391-407$.

Greene, W. H. (2003). Econometric analysis. New Jersey: Prentice Hall, pp. 1024.

Griffith, R., Harrison, R., \& Van Reenen, J. (2008). How special is the special relationship? Using the impact of US R\&D spillovers on UK firms as a test of technology sourcing. American Economic Review, 96(5), 1859-1875.

Griliches, Z. (1990). Patent statistics as economic indicators-A survey. Journal of Economic Literature, 28(4), 1661-1707.

Guellec, D., \& Van Pottelsberghe, B. (2001). The internationalisation of technology analysed with patent data. Research Policy, 30(8), 1256-1266.

Gupta, A. K., \& Govindarajan, V. (2000). Knowledge flows within multinational corporations, Strategic Management Journal, $21,473-496$.

Hakanson, L., \& Nobel, R. (1993). Foreign research and development in Swedish multinationals. Research Policy, 22, $373-396$.

Hall, B. H., Griliches, Z., \& Hausman, J. A. (1983). Patents and R\&D: Searching for a lag structure. NBER Working paper no. 1227.

Hall, B. H., Link, A., \& Scott, J. (2003) Universities as research partners, The Review of Economics and Statistics, 85(2), 485-491.

Harhoff, D, Mueller, E., \& van Reenen, J. (2014). What are the channels for technology sourcing? Panel data evidence from German companies. Journal of Economics and Management Strategy, 23(1), 204-224.

Harhoff, D., Scherer, F., \& Vopel, K. (2003). Citations, family size, opposition and the value of patent rights. Research Policy, $32,1343-1363$.

Head, K., Ries, D., \& Swanson, L. (1995). Agglomeration benefits and location choices: Evidence from Japanese manufacturing investments in the United States. Journal of International Economics, 38, 223-247.

Hegde, D., \& Hicks, D. (2008). The maturation of global corporate R\&D: Evidence from the activity of U.S. foreign subsidiaries. Research Policy, $27(3), 390-406$

Hicks, D., Ishizuka, T., Keen, P., \& Sweet, S. (1994). Japanese corporations, scientific research and globalization. Research Policy, $23,375-384$.

Hoetker, G., (2007). The use of logit and probit models in strategic management research: Critical issues. Strategic Management Journal, $28,331-343$.

Iwasa, T., \& Odagiri, H. (2004). Overseas R\&D, knowledge sourcing, and patenting: An empirical study of Japanese R\&D investment in the US. Research Policy, 33(5), 807-829.

Jaffe, A., (1989). Real effects of academic research. American Economic Review, 79, 957-970.

Kenney, M., \& Florida, R. (1994). The organization and geography of Japanese R\&D: Results from a survey of Japanese electronics and biotechnology firms. Research Policy, 23, 305-323.

Khan, M., \& Dernis, H. (2006). Global overview of innovative activities from the patent indicators perspective. OECD Science, Technology and Industry Working papers, 2006/3, Paris: OECD Publishing.

Klevorick, A., Levin, R., Nelson, R., Winter, S. (1995). On the sources and significance of inter-industry differences in technological opportunities. Research Policy, 24(2), 185-205.

Kuemmerle, W. (1997). Building effective R\&D capabilities abroad. Harvard Business Review, 75, 61-70.

Kuemmerle, W. (1999). The drivers of foreign direct investment into research and development: An empirical investigation. Journal of International Business Studies, 30(1), 1-24.

Kumar, N. (2001). Determinants of location of overseas R\&D activity of multinational enterprises: The case of US and Japanese corporations. Research Policy, 30(1), 159-174.

Lahiri, N. (2010). Geographic distribution of R\&D activity: How does it affect innovation quality. Academy of Management Journal, 53(5), 1194-1200.

Laursen, K., Reichstein, T., \& Salter, A. (2011). Exploring the effect of geographical proximity and university quality on university-industry collaboration in the United Kingdom. Regional Studies, 45(4), 507-523.

Le Bas, C., \& Sierra, C. (2002). Location versus home country advantages in R\&D activities: Some further results on multinationals location strategies. Research Policy, 31, 589-609.

Leten, B., Landoni, P., \& Van Looy, B. (2014). Science or graduates: How do firms benefit from the proximity of universities?. Research Policy, 43, $1398-1412$.

Lewin, A., Massini, S., \& Peeters, C. (2009). Why are companies offshoring innovation? The emerging global race for talent. Journal of International Business Studies, 40, 901-925.

Liebeskind, J. P., Oliver, A. L., Zucker, L., \& Brewer, M. (1996). Social networks, learning, and flexibility: Sourcing scientific knowledge in new biotechnology firms. Organization Science, 7(4), 428-442. 
Lim, K. (2004). The relationship between research and innovation in the semiconductor and pharmaceutical industries (1981-1997). Research Policy, $33,287-321$.

Link, A. N., Siegel, D. S., \& Bozeman, B. (2007). An empirical analysis of the propensity of academics to engage in informal university technology transfer. Industrial and Corporate Change, 16(4), 641-655.

Mansfield, E. (1995). Academic research underlying industrial innovations: Sources, characteristics and financing. The Review of Economics and Statistics, 77, 55-65.

Mansfield, E. (1998). Academic research and industrial innovation: An update of empirical findings. Research Policy, 26, 773-776.

Nachum, L., Zaheer, S., \& Gross, S. (2008). Does it matter where countries are? Proximity to knowledge, markets and resources, and MNE location choices. Management Science, 54(7), 1252-1265.

Narin, F., \& Noma, E. (1985). Is technology becoming science? Scientometrics, 7, 369-381.

Nieto, M. J., \& Rodriguez, A. (2011). Offshoring of R\&D: Looking abroad to improve innovation performance. Journal of International Business Studies, 42, 345-361.

Nobel, R., \& Birkinshaw, J. (1998). Innovation in multinational corporations: control and communication patterns in international R\&D operations. Strategic Management Journal, 19(5), 479-496.

OECD (2007). Intellectual assets and international investment: A stocktaking of the evidence. Report to the OECD Investment Committee, DAF/INV/WD(2007)6. Paris: OECD.

Okamuro, H., \& Nishimura, J. (2013). Impact of university intellectual property policy on the performance of university-industry research collaboration. Journal of Technology Transfer, 38(3), 273-301.

Park, W., \& Wagh, S. (2002). Index of patent rights. In: Economic Freedom of the World 2002 Annual Report, 33-43. Calgary: Fraser Institute.

Patel, P., \& Vega, M. (1999). Patterns of internationalisation of corporate technology: Location vs. home country advantages. Research Policy, 28, 145-155.

Pavitt, K. (1991). What makes basic research economically useful? Research Policy, 20, 109-119.

Penner-Hahn, J., \& Shaver, M. (2005). Does international research and development increase patent output? An analysis of Japanese pharmaceutical firms. Strategic Management Journal, 26, 121-140.

Phene, A., \& Almeida, P. (2008). Innovation in multinational subsidiaries: The role of knowledge assimilation and subsidiary capabilities. Journal of International Business Studies, 39(5), 901-919.

Rosenberg, N. (1990). Why do firms do basic research (with their own money)? Research Policy, 19(2), 165-174.

Shaver, J., \& Flyer, F. (2000). Agglomeration economies, firm heterogeneity, and foreign direct investment in the United States. Strategic Management Journal, 21(12), 1175-1193.

Shimizutani, S., \& Todo, Y. (2007). What determines overseas R\&D activities? The case of Japanese multinational firms. Research Policy, $37,530-544$.

Singh, J. (2007). Asymmetry of knowledge spillovers between MNCs and host country firms. Journal of International Business Studies, 38(5), $764-786$.

Singh, J. (2008). Distributed R\&D, cross-regional knowledge integration and quality of innovative output. Research Policy, 37(1), 77-96.

Song, J., Asakawa, K., \& Chu, Y. (2011). What determines knowledge sourcing from host locations of overseas R\&D operations? A study of global R\&D activities of Japanese multinationals. Research Policy, 40(3), 380-390.

Teece, D., Pisano, G, \& Shuen, A. (1997). Dynamic capabilities and strategic management. Strategic Management Journal, 18(7), 509-533.

Thursby, J., \& Thursby, M. (2006). Here or there? A survey of factors in multinational R\&D location. Report to the Government-University-Industry Research Roundtable. Washington, DC: The National Academies Press.

Tijssen, R. (2001). Global and domestic utilization of industrial relevant science: Patent citation analysis of science-technology interactions and knowledge flows. Research Policy, 30, 35-54.

Todo, Y., \& Shimizutani, S. (2008). Overseas R\&D activities and home productivity growth. Journal of Industrial Economics, 56(4), $752-777$.

UNCTAD (2005). World Investment Report 2005. New York: United Nations.

Van Looy, B., Tijssen, R. J. W., Callaert, J., Van Leeuwen, T., \& Debackere, K. (2004) European science in industrial relevant research areas: Development of an indicator-based bibliometric methodology for performance analyses of countries and research organizations. Report for the European Commission (DGResearch) produced by the Centre for Science and Technology Studies, Leiden (CWTS) and International Centre for Studies in Entrepreneurship and Innovation Management. Leuven: INCENTIM.

Van Pottelsberghe de la Potterie, B., \& Guellec, D. (2007). The Economics of the European Patent System. Oxford: Oxford University Press.

Van Vianen, B., Moed, H., \& Van Raan, A. (1990). An exploration of the science base of recent technology. Research Policy, $19,61-81$.

Von Zedtwitz, M., \& Gassmann, O. (2002). Market versus technology drive in R\&D internationalization: four different patterns of managing research and development. Research Policy, 31(4), 569-588.

Zucker, L., Darby, M., \& Armstrong, J. (2002). Commercializing knowledge: University science, knowledge capture, and firm performance in biotechnology. Management Science, 48(1), 138-153. 
Zucker, L., Darby, M., \& Brewer, M. (1998). Intellectual human capital and the birth of U.S. biotechnology enterprises. American Economic Review, 88(1), 290-306.

How to cite this article: Belderbos R, Leten B, Suzuki S. Scientific research, firm heterogeneity, and foreign R\&D locations of multinational firms. J Econ Manage Strat. 2017;26:691-711. https://doi.org/10.1111/jems.12205

\section{APPENDIX}

Descriptive statistics and correlations

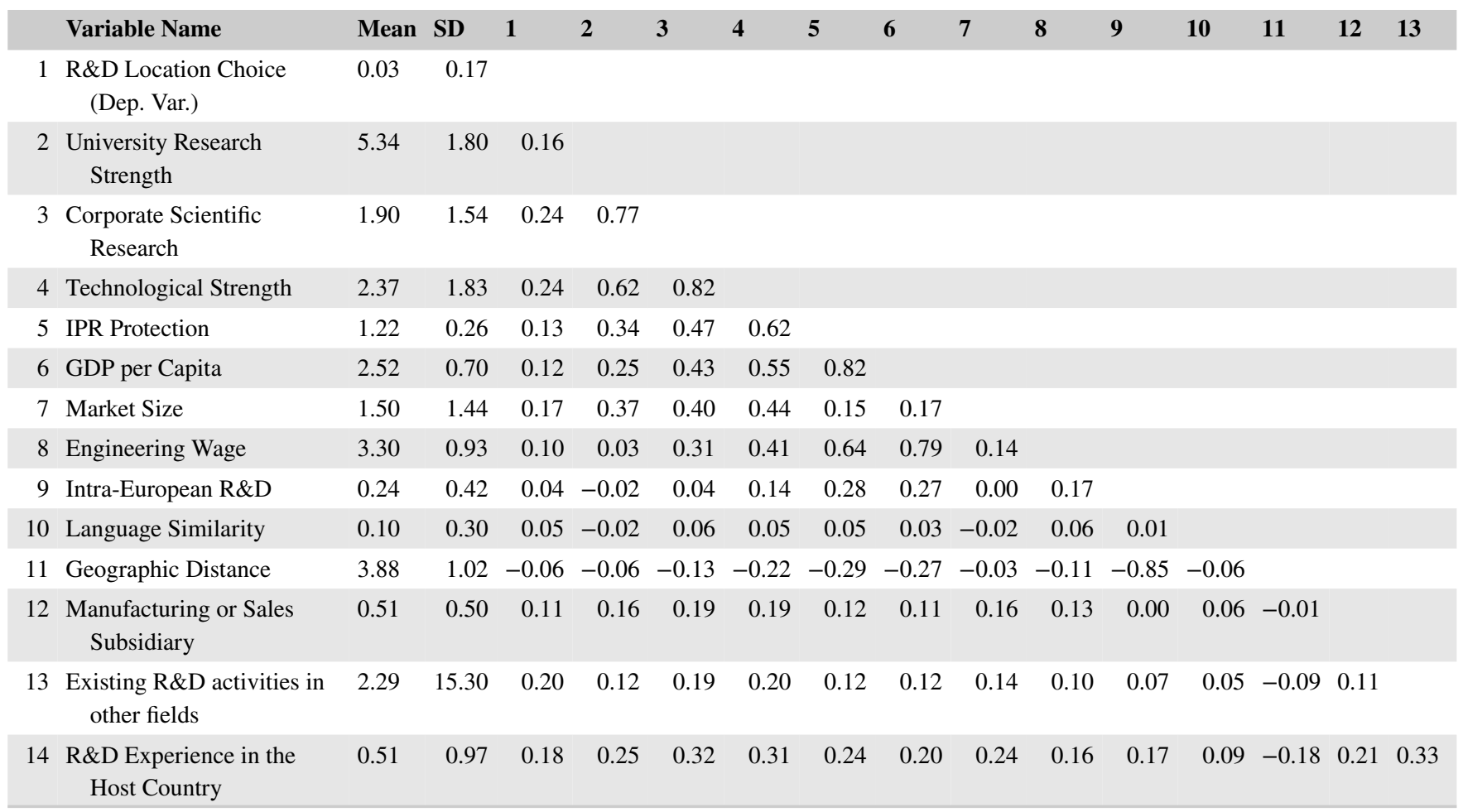

Note: $\mathrm{SD}=$ standard deviation. 